\title{
Advances of the experimental models of idiopathic membranous nephropathy (Review)
}

\author{
HAN XUE JIANG ${ }^{1,2 *}$, ZHENDONG FENG ${ }^{3 *}$, ZE BING ZHU ${ }^{1,2}$, CHEN HUI XIA ${ }^{1,2}$, WENTING ZHANG ${ }^{1,2}$, \\ JING GUO $^{1,2}$, BAO-LI LIU ${ }^{4}$, YAOXIAN WANG ${ }^{1,2}$, YU NING LIU ${ }^{1,2}$ and WEI JING LIU ${ }^{1,2}$ \\ ${ }^{1}$ Key Laboratory of Chinese Internal Medicine of The Ministry of Education and Beijing, Dongzhimen Hospital Affiliated \\ to Beijing University of Chinese Medicine; ${ }^{2}$ Renal Research Institution, Beijing University of Chinese Medicine, \\ Beijing 100700; ${ }^{3}$ Beijing Chinese Medicine Hospital Pinggu Hospital, Beijing 101200; ${ }^{4}$ Department of Nephrology, \\ Beijing Traditional Chinese Medicine Hospital, Capital Medical University, Beijing 100010, P.R. China
}

Received September 14, 2019; Accepted February 14, 2020

DOI: $10.3892 / \mathrm{mmr} .2020 .11014$

\begin{abstract}
Idiopathic membranous nephropathy (IMN) is one of the main types of chronic kidney disease in adults and one of the most common causes of end-stage renal disease. In recent years, the morbidity of IMN among primary glomerular diseases has markedly increased, while the pathogenesis of the disease remains unclear. To address this, a number of experimental models, including Heymann nephritis, anti-thrombospondin type-1 domain-containing 7A antibody-induced IMN, cationic bovine serum albumin, anti-human podocyte antibodies and zymosan-activated serum-induced C5b-9, have been established. This review comprehensively summarized the available animal and cell models for IMN. The limitations and advantages of the current models were discussed and two improved models were introduced to facilitate the selection of an appropriate model for further studies on IMN.
\end{abstract}

\section{Contents}

1. Introduction

2. Rat models of IMN

3. Mouse models of IMN

4. Limitations and advantages of the animal models

5. Cell models of IMN

6. Limitations and advantages of the cell models

Correspondence to: Dr Wei Jing Liu or Dr Yu Ning Liu, Key Laboratory of Chinese Internal Medicine of The Ministry of Education and Beijing, Dongzhimen Hospital Affiliated to Beijing University of Chinese Medicine, 5 Hai Yun Cang, Dongcheng, Beijing 100700, P.R. China

E-mail: liuweijing-1977@hotmail.com

E-mail: yunin1946@sina.com

${ }^{*}$ Contributed equally

Key words: idiopathic membranous nephropathy, chronic kidney disease, model, phospholipase A2 receptor, thrombospondin type-1 domain-containing 7A antibody
7. Pathogenesis of IMN: From model to human

8. Potential future models

\section{Introduction}

Chronic kidney disease (CKD) is becoming a serious public health problem because it is related to an increased risk of cardiovascular disease and mortality (1-4). As one of the main types of CKD, membranous nephropathy (MN), is an autoimmune disease characterized by diffuse deposition of immune complexes under glomerular epithelial cells (GECs), with diffuse thickening of the glomerular basement membrane (GBM) $(5,6)$. According to primary diseases, $\mathrm{MN}$ can be categorized into idiopathic membranous nephropathy (IMN) and secondary membranous nephropathy (SMN), while IMN accounts for approximately $80 \%$ of the total incidence of MN (7). In recent years, the morbidity of IMN in China significantly increased from $6.48 \%$ between 1997 and 1999 to $22.79 \%$ between 2009 and 2011 (8-11). The clinical prognosis of IMN varies greatly. Among untreated patients, approximately one third undergo spontaneous remission, one-third progress to end-stage renal disease over 10 years and the remainder develop non-progressive CKD. In short, approximately two-thirds of cases progress to CKD (12-15). Thus far, no curative therapies have been achieved for CKD or IMN $(16,17)$, which may be attributed to unclear mechanisms. Therefore, the establishment of ideal model for IMN is important for mechanism research and a number of studies have tried to establish new models (18-21). This review comprehensively discussed the available animal and cell models for IMN. The limitations and advantages of the current models were discussed and two improved models were provided. Overall, this review could enable the selection of an appropriate model for studies on IMN and further the current understanding of human IMN.

\section{Rat models of IMN}

Heymann nephritis model. Heymann nephritis, also known as homologous immune complex nephritis, is a widely used model of MN (22). On the basis of whether the antibodies 
are autologous or homologous or not, Heymann nephritis is divided into active and passive nephritis models (23). In 1959, Heymann et al (24) used autogenous or homologous rat homogenized proximal tubular brush border in immune rats to develop a model of nephritic syndrome, known as active Heymann nephritis (AHN). AHN is characterized by granular glomerular capillary wall deposits of rat immunoglobulin $\mathrm{G}(\mathrm{IgG})$ and subepithelial electron-dense deposits after 3-4 weeks. It has been demonstrated that 30-80\% of AHN rats developed proteinuria within 8-10 weeks after immunization (25). Another study demonstrated that injected rats with resistance to the proximal tubule brush border antigen (Fx1A) antibodies also showed IgG, C3 and C5b-9 depositions under the glomerular epithelium and a significant level of proteinuria (26). This is termed passive Heymann nephritis. It indicates that the subepithelial deposits are formed by the circulating antibodies combining with the intrinsic antigen in the glomerulus rather than by the circulating immune complex. In this model, subepithelial electron-dense deposits should be detectable after 3-5 days of injecting anti-FxlA and rats developed persistent proteinuria after about 7-10 days (27).

The pathogenesis of Heymann nephritis has been a controversial issue for a long time. At present, its antigen, mainly megalin (gp330), is believed to exist in the brush border of the proximal convoluted tubule and epithelial cell membrane of the glomerulus (24,28-30). In animal models, active immunization with megalin resulted in immune complex deposition under the epithelium of the glomerulus, without activation of $\mathrm{C} 3$ or $\mathrm{C} 5 \mathrm{~b}-9$ and proteinuria. However, when the animals were injected with antibodies against megalin monoclonal antibody and complement regulatory proteins such as cluster of differentiation (CD)59 and CR1-related gene/protein Y at the same time, pathological proteinuria occurred (31). These studies confirm that the membrane attack complex (MAC; C5b-9) formed by the activation of the immune complex is the main inflammatory mediator of Heymann nephritis and is closely related to the production of pathological proteinuria $(32,33)$. Furthermore, although megalin is expressed in human podocytes $(34,35)$, it is not detected in the glomerular subepithelial immune complex and no circulating anti-megalin antibodies are found in patients with IMN (36). In addition, the complement pathway and subclass of $\operatorname{IgG}$ in this model are still unknown (37-39). Therefore, it is not equivalent to human IMN.

Anti-dipeptidyl peptidase IV model. Dipeptidyl peptidase IV (DPP IV) is identified as a major antigen (gp108) of FxlA (40), which is mainly expressed on the brush borders of renal tubules, intestinal microvilli and glomerular capillary loops. After injecting rabbit anti-DPP IV in the rats, the rabbit IgG was deposited in the glomerular capillary loops for 4-8 $\mathrm{h}$ and proteinuria occurred within $8 \mathrm{~h}$. After 2 days, proteinuria peaked and then rapidly decreased. To find the target antigen, serum DPP IV-depleted rats were used and similar results were obtained. The results suggest that DPP IV located along the glomerular capillary wall plays an important role in the induction of proteinuria (40). Compared with the model induced by gp330, this method induced the activation of a urinary protein that appears transiently, no deposition of C3 and faster disappearance of $\mathrm{IgG}$ (41). Taken together, these efforts reveal the target antigen in $\mathrm{MN}$ and the pathogenesis of the kidney disease model.

\section{Mouse models of IMN}

Thrombospondin type-1 domain-containing 7A-associated MN model. Thrombospondin type-1 domain-containing 7A (THSD7A), which was identified in 2014 , is one of the target podocyte autoantibodies in IMN (42). These receptors are type I transmembrane glycoproteins consisting of three regions, namely the transmembrane domain, short intracellular C-terminal tail and large extracellular domain $(43,44)$. In the human glomerulus, THSD7A is commonly expressed in foot processes, with observation of $250 \mathrm{kDa}$ proteins (45) in non-reducing states. The intrinsic antigen respectively binds to anti-THSD7A IgG from the serum of the patient with $\mathrm{MN}$, forming immune complexes in situ along with the glomerular filtration barrier (GFB) (46).

Previous findings have demonstrated that THSD7A is strongly expressed in murine podocyte (47). This has enabled the establishment of a model of THSD7A-related MN, which is closer to human IMN (Fig. 1). Tomas et al (20) injected human anti-THSD7A antibody-containing serum in mice and demonstrated that human anti-THSD7A autoantibodies can specifically bind to mouse (m)THSD7A. The mice manifest significant albuminuria around day 3 and until day 70 . The researchers observed a granular pattern on the subepithelial aspect of the GFB, huIgG-mTHSD7A colocalization and immune complex deposition. In addition, immunofluorescence staining analyses revealed complement C3 accumulations within the subepithelial granular pattern. Consistent with the above-mentioned results, electron microscopic images showed electron-dense deposits with a strictly subepithelial localization and extensive foot process effacement around the local regions.

In the following year, a heterologous model of THSD7A-associated MN was introduced (48). First, the researchers generated rabbit anti-THSD7A antibodies by co-immunization with a combination of mTHSD7A and human (h)THSD7A cDNAs. Then, the mice were injected with anti-THSD7A IgG purified from rabbit serum. The mice that received rabbit IgGs developed severe nephritic syndrome and the albumin-to-creatinine ratio increased gradually during the entire observation period of 14 days. The mice presented the same histopathological changes as the abovementioned THSD7A-associated model, with the only differences being the unknown IgG hypotype and undetected C3 (Table I).

Anti-aminopeptidase A (APA) model. APA is a hydrolase present in the kidney of mice and is mainly located on the podocyte membrane and the brush border of proximal tubules. The model was established by injecting anti-APA monoclonal antibodies in mice (49). The visible antibodies, belonging to the IgG1 subclass, are widely distributed in the GEC membrane and proximal tubular S1 and S2 brush borders. The dose-dependent proteinuria lasted for 16 days and podocyte foot processes fused but lacked activation of the complement system. Subsequently, another study demonstrated that injection of anti-APA monoclonal antibody can cause two slit-pore-associated proteins, CD2-associated 


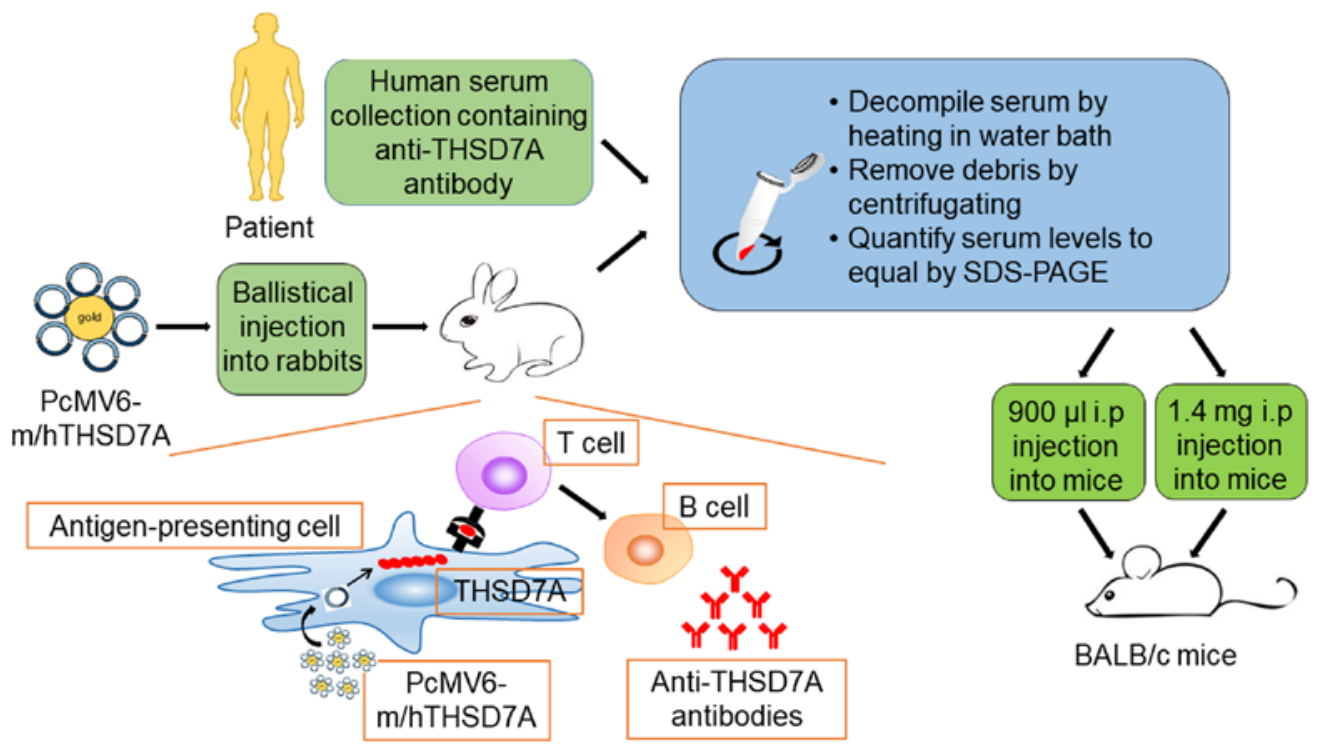

Figure 1. Establishment of two kinds of animal models of THSD7A. The antigen-presenting cell of the skin takes up pCMV6-m/hTHSD7A, which leads to the production of the full-length mTHSD7A and hTHSD7A in the antigen-presenting cell. Then, the encoded proteins are presented to the T cell through the peptide $\mathrm{MHC}$, inducing the proliferation and differentiation of $\mathrm{T}$ cells, which produce helper $\mathrm{T}$ lymphocytes. With the assistance of helper $\mathrm{T}$ lymphocytes, $\mathrm{B}$ cells are activated, producing antibodies against THSD7A in rabbits. THSD7A, thrombospondin type-1 domain-containing 7A; $\mathrm{m}$, mouse; $\mathrm{h}$, human.

protein (CD2AP) and podocin structural alteration, which may be the underlying mechanism of proteinuria (50).

Cationic bovine serum albumin model. According to the negative characteristic of the GBM, injecting rabbits with cationic bovine serum albumin (C-BSA) daily ( $\mathrm{pI}>9.5)$ intravenously induced proteinuria and nephrotic syndrome approximately 2 weeks later (51). Immunofluorescence showed IgG, C3 and other granule depositions in the GBM (52). Electron microscopy revealed subepithelial electron-dense deposits and irregular GBM thickening may occur in the later stages of the disease. To examine the mechanism of this model, C-BSA was injected in the renal artery to block the blood circulation after rinsing the rabbit kidney thoroughly with saltwater and anti-BSA antibodies were subsequently injected. Under immunofluorescence, immune complex particle sample distribution was observed along the glomerular capillary wall, which provided evidence that the pathogenesis of the C-BSA model did not involve circulating immune complex deposition in the glomerulus but immune complex deposition in situ (53). Chen et al (54) believed that this model is due to the C-BSA deposited in the GBM, which is full of negative charge and the corresponding antibody (principally IgG1), produced by its own form of immune complex in situ, activates the complement pathway. Debiec et al (55) found bovine serum albumin in subepithelial immune deposits in children with $\mathrm{MN}$, demonstrating C-BSA binding to the anionic glomerular capillary wall and subsequent formation of IC in situ. They hypothesized that C-BSA may be one of the main pathogenic targets in childhood $\mathrm{MN}$, especially in children aged $<5$ years.

Anti-a3NC1 mouse model. The non-collagen 1 domain of human $\alpha 3$ (IV) collagen $(\alpha 3 \mathrm{NC} 1)$ is a normal constituent of the GBM. Zhang et al (56) hypothesized that owing to its higher isoelectric point ( $\mathrm{pI}$ 9), it may be conducive to the formation of GBM deposition, similar to the mechanism of C-BSA. Zhang et al (56) used mice immunized with $\alpha 3 \mathrm{NC} 1$ to develop clinical and histopathological features of IMN. The extent and quality of autoimmunity against $\alpha 3 \mathrm{NCl}$ and $\mathrm{T}$-cell responses are critical to the severity of nephropathy (57). Compared with other models, the prominent advantage is that regulation of gene expression is possible since mice are used. Furthermore, the model can be developed rapidly and reliably. Luo et al (58) found that factor B-null mice lacked glomerular deposition of C3 and C5b-9 and did not develop albuminuria. Albuminuria was reduced but not completely abolished in the C5-deficient mice. It indicates that the alternative pathway is necessary for pathogenic complement activation. Only the DBA/1 mice are associated with a high success rate for mouse modeling and other mice have a certain degree of resistance to $\alpha 3 \mathrm{NC} 1$ and cannot be used for developing such models (59).

Anti-podocyte nephritis model. The anti-podocyte nephritis (APN) (60) model is created by injecting murine podocytes as antigens in allogeneic animals to produce antibodies; the immune serum is then injected back in the murine animal. This model can show large amounts of proteinuria and deposition of immune complexes. The deposited immune complex is mainly $\mathrm{IgG}$, but the subclass may be different from that in humans and the amount of C3 deposition is minimal (61). The uses of podocyte antibodies produced in rabbits and mice are different. Antibodies produced by rabbit immunization do not affect mice and produce immune complexes by themselves, one needs to preimmunize mice with Freunds adjuvant. However, the monoclonal antibody produced by goat immune podocytes can cause nephrotic syndrome and epithelial immune complex formation. Through isolation of immunoreactive goat IgG and mass spectrometric analysis, the target antigen in the APN model was found to be Annexin 3 and researchers found a positive Annexin 3 expression in the renal tissue of patients (62). However, confirming whether 
Table I. Similarities and differences between human and rabbit IgGs of THSD7A-associated MN.

\begin{tabular}{|c|c|c|}
\hline Feature & Human IgG associated model & Rabbit IgG associated model \\
\hline \multicolumn{3}{|l|}{ Similarities } \\
\hline Animal & BALB/c mice & $\mathrm{BALB} / \mathrm{c}$ mice \\
\hline MN histomorphology & $\begin{array}{l}\text { Granular subepithelial IgG deposition, } \\
\text { subepithelial immune deposits, broadening } \\
\text { of podocyte foot processes }\end{array}$ & More pronounced and extensive \\
\hline Proteinuria & Significant proteinuria from day 3 & $\begin{array}{l}\text { Massive proteinuria from day } 3 \text {, } \\
\text { nephrotic syndrome }\end{array}$ \\
\hline Initiation reaction & huIgG-mTHSD7A & Rabbit IgG-mTHSD7A \\
\hline \multicolumn{3}{|l|}{ Differences } \\
\hline Source of serum & Human with MN & Rabbit without MN \\
\hline Injection & Whole serum from the patient & Purified IgG from rabbit \\
\hline $\operatorname{IgG}$ in mice & huIgG, mIgG & Rabbit IgG \\
\hline Complement C3 & Present & Absent \\
\hline Nephritic syndrome & Unpublished data & Serious \\
\hline Application & Rodents studied & Not all rodent species \\
\hline Establish & Comparatively simple & Comparatively complex \\
\hline
\end{tabular}

THSD7A, thrombospondin type-1 domain-containing 7A; MN, membranous nephropathy; IgG, immunoglobulin G.

this is another antigen of IMN as M-type phospholipase A2 receptor (M-PLA2R) requires further research (63).

\section{Limitations and advantages of the animal models}

Owing to different preparation methods, the abovementioned models all have limitations or advantages. Active Heymann nephritis is an autoimmune disease model and more closely resembles human membranous nephropathy, thus, it is more suitable for the study of the immune mechanism. However, it usually has large individual variability, which makes it unsuitable for studies of pharmacodynamics and injury (25). The passive Heymann nephritis model is widely used as it is relatively stable and its pathological changes are similar to human MN. The anti-DPP IV model is different from the pathological manifestation of human IMN due to C3 deficiency (47). The THSD7A-associated MN model is comparable to human IMN as a result of the common THSD7A antigen in mice and humans, similar to the complement activation pathways (lectin pathway) (64) and the common subclass of IgG (IgG4). However, the detection rate of THSD7A is approximately $3 \%$ in all patients with IMN $(65,66)$. This model may not represent the pathogenesis and all pathological changes of IMN. Further, it is similar to the Heymann nephritis model, which is induced by the binding of antigens and antibodies. The C-BSA model is a new tool for IMN study that has a relatively low cost, simple operation and wide application. In addition, the degree of pathological changes is related to the dose; thus, models of different stages of IMN can be developed. The limitations of the model include the high mortality due to several tail vein injections and dosage. A unified standard to establish a model that reflects conditions in young children is imperative. As in the anti-aminopeptidase A, anti- $\alpha 3 \mathrm{NC} 1$ mouse and APN models, although these models show different pathogenesis that of human IMN and are currently underutilized, they can still be used to examine the pathogenesis of IMN. For example, a study suggested that the incidence of IMN is closely associated with the lungs (67), as in the anti- $\alpha 3 \mathrm{NC} 1$ mouse model.

\section{Cell models of IMN}

Anti-THSD7A antibody induced podocyte model. Except for the animal model of THSD7A-related $\mathrm{MN}$, in vitro results suggested that anti-THSD7A antibodies may also directly influence the integrity of podocyte (Fig. 2). Immortalized cultured murine or human podocyte cell lines do not express THSD7A at detectable protein levels and thus primary GECs are used. Exposure of GECs to anti-THSD7A antibody-containing serum results in the binding of huIgG to the cell membrane and a change in the cytoskeletal organization, accompanied by altered focal adhesions. When the model was recreated in 293 cells, the results suggested a direct influence of anti-THSD7A antibodies on the cytoskeletal organization (20).

Zymosan-activated serum (ZAS)-induced podocyte model. Research on zymosan began in the 1940s. It is a non-specific immune system stimulatory substance, existing in the yeast cell wall (68). Some researchers used zymosan to assemble C5b-9 complement complexes, which were developed to interfere with mouse serum to obtain ZAS. Subsequently, ZAS was applied to stimulate podocytes to develop the MN model in vitro (69-71) (Fig. 3).

Zymosan can promote rapid C3 cleavage in the alternate pathway (AP) through assembly and protection of the amplification convertase on its surface. It is different from the classic complement pathway (CP), in which the antigen-antibody complexes bind and convert $\mathrm{C} 1$ to its activated state on cell 


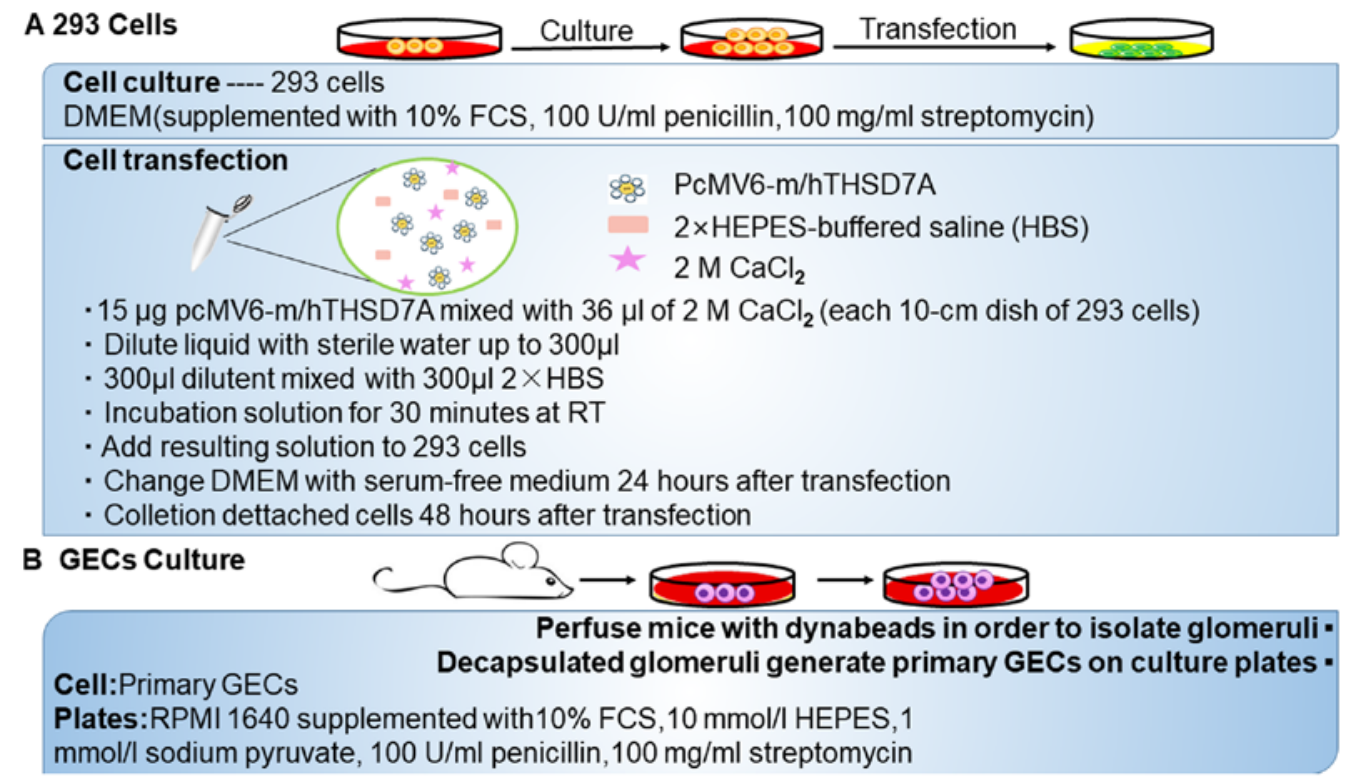

Figure 2. Development of two kinds of cell models of THSD7A. (A) The method of 293 cell culture and transfection. (B) The method for primary glomerular epithelial cell culture. THSD7A, thrombospondin type-1 domain-containing 7A.

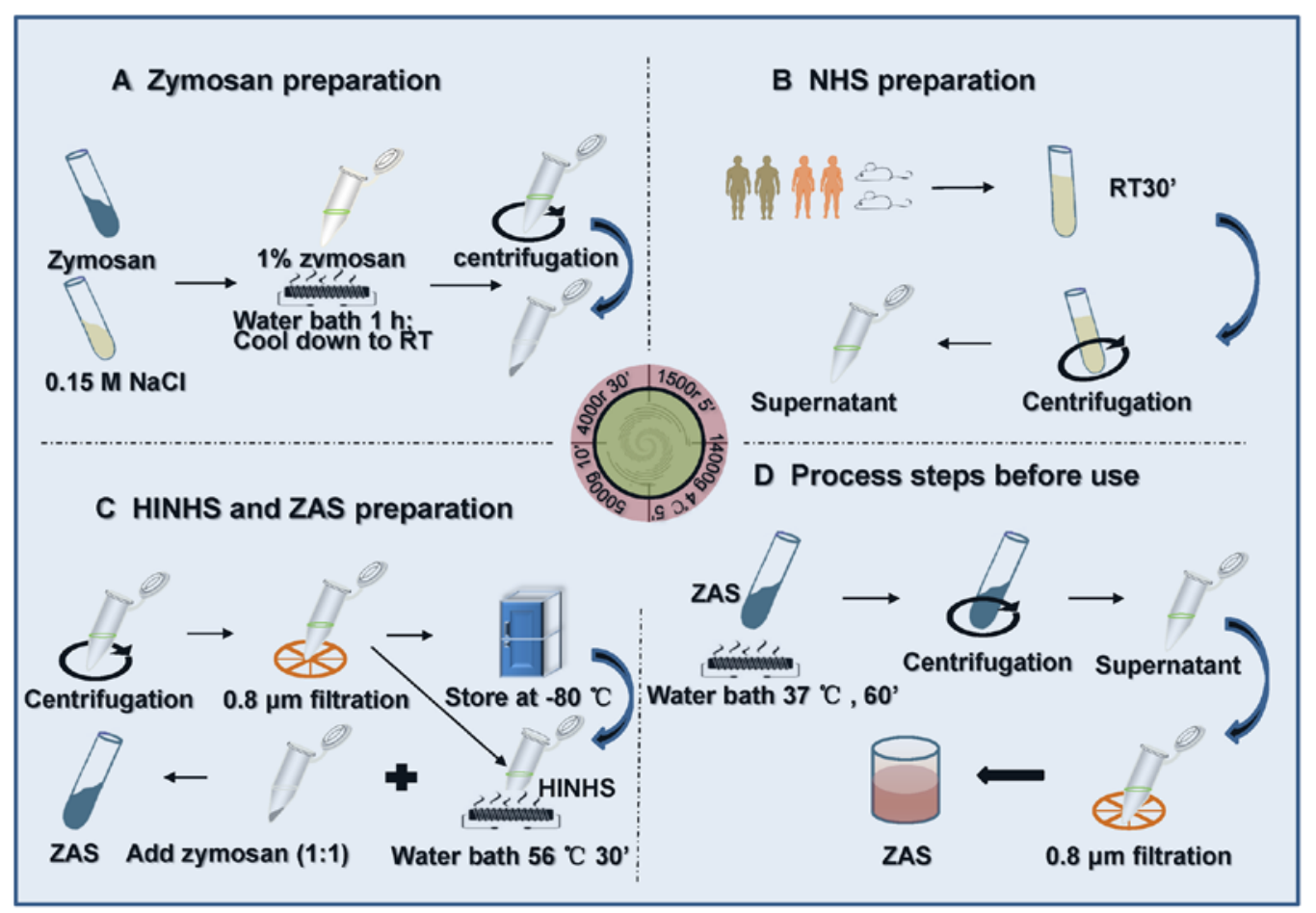

Figure 3. Preparation method of ZAS. (A-D) After $1 \mathrm{~h}$ exposure of podocytes to ZAS at different dilutions, the release rate of lactate dehydrogenase was determined to identify the optimum concentration of ZAS. NHS, normal human serum; HINHS, heat-inactivated normal human serum; ZAS, zymosan-activated serum.

membranes (72). However, the formation of C5b-9 by zymosan induces antibody-independent complement activation in the fluid phase via the AP, which differs from that assembled on cell membranes via the CP (73,74). Zymosan, one of the major activators of the AP, provides a contact surface that initiates the complement cascade process by directly activating $\mathrm{C} 3$ in serum without apparent utilization of $\mathrm{C} 1, \mathrm{C} 4$ or $\mathrm{C} 2$ (72). Subsequently, the AP surface-bound C3 and C5 convertases assembled on zymosan particles initiate the production of the C5b-9 complex $(75,76)$.
To assemble sublytic C5b-9 MAC in the fluid phase, normal human serum is treated with zymosan as previously reported $(70,77)$. Then, the zymosan particles are removed from the serum sample by centrifugation. In addition, the output rate of C5b-9 can be measured using an anti-human C5b-9 monoclonal antibody, which can specifically bind with the C5b-9 complex and then be removed from serum by immunoprecipitation, as previously described (70). The alteration in the membrane integrity of podocytes could be determined by measuring the release of the intracellular enzyme lactate dehydrogenase (76). 


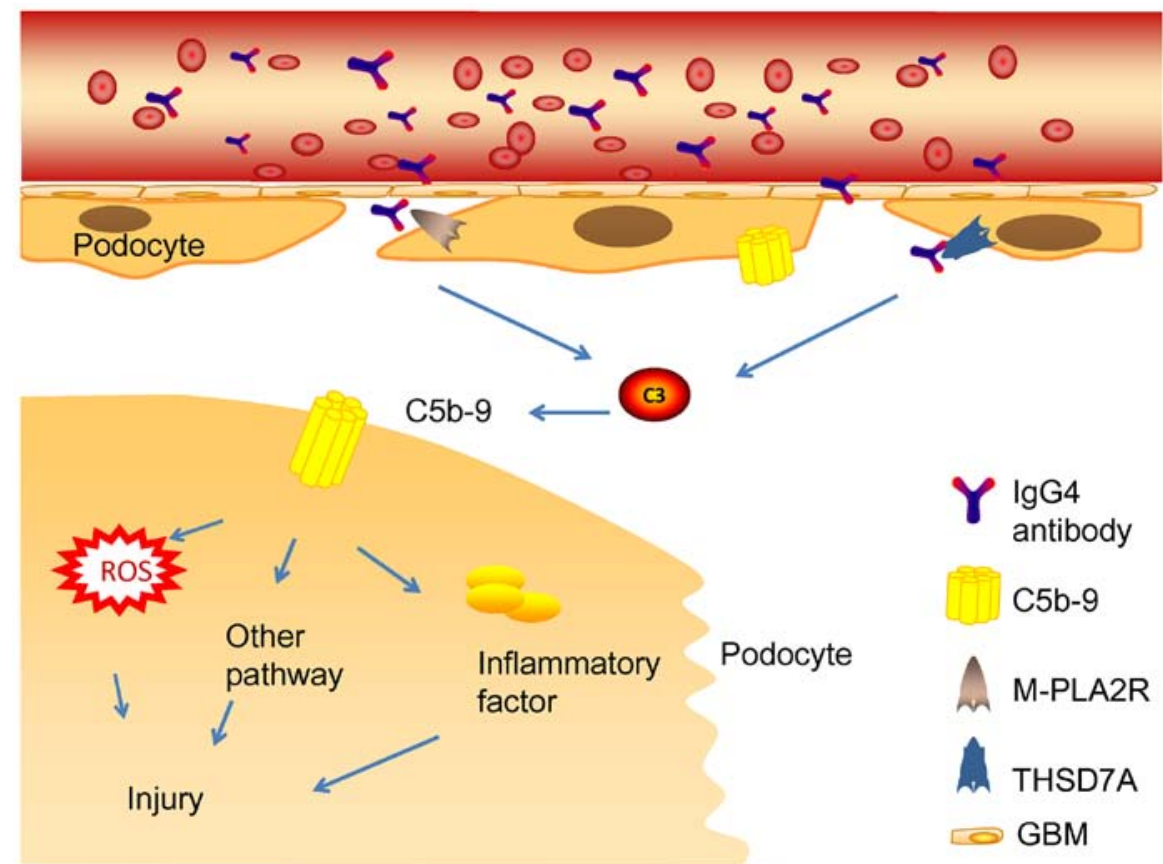

Figure 4. Mechanism of human membranous nephropathy. The combination of autoantibodies and antigens exposed in the podocytes activated the complement system, forming the membrane attack complex (MAC, C5b-9) in situ and caused podocyte injury and proteinuria. MAC, membrane attack complex; ROS, reactive oxygen species; IgG, immunoglobulin G; M-PLA2R, M-type phospholipase A2 receptor; THSD7A, thrombospondin type-1 domain-containing 7A; GBM, glomerular basement membrane.

\section{Limitations and advantages of the cell models}

Experiment in vitro is the indispensable method to examine podocyte damage. The anti-THSD7A antibody and ZAS-induced podocyte model could simulate the mechanism of C5b-9 or anti-THSD7A antibody damage to podocytes. They have insufficient levels of evidence and cannot fully simulate the pathogenesis of human IMN. Compared with the ZAS-induced podocyte model, as THSD7A is an autoantigen can be detected in patients with MN, anti-THSD7A model can more accurately reappear the pathogenesis of MN. In addition, according to practical experience, the source of serum required for the preparation of the ZAS model is relatively extensive. For example, human, rat and mice sera can all be used. However, the physiological status of the blood sample will affect the C5b-9 output rate $(70,72)$.

\section{Pathogenesis of IMN: From model to human}

At present, the pathogenesis of IMN is remains to be elucidated. A number of studies have demonstrated the pathogenesis of immunological damage (78-80). IMN is believed to be an autoimmune disease. As a result, research on IMN has shifted from verifying the Heymann nephritis hypothesis to further studying immune mechanisms. The current research on IMN mainly focused on complement activation, the specific antigen, IgG4 and gene.

Glomerular subepithelial immune complexes play a vital role in the pathogenetic mechanism of MN (14). The activation of the complement system induces the production of MAC (C5b-9). Complement system activation and MAC formation cause inflammatory mediator release and podocyte damage (81) (Fig. 4). Generally, immune complexes are the major substances that activate the CP (82). Nevertheless, it remains undiscovered as a pathway to complement system activation by IgG4 immune complexes in phospholipase A2 receptor 1 (PLA2R1) and THSD7A-associated MN (83-85). IgG4 could hardly activate the $\mathrm{CP}$ because of its low affinity to $\mathrm{Clq}$ or $\mathrm{Fc} \gamma$ receptors (86). Such studies support the hypothesis that the lectin pathway may be the main initiation pathway (87). In line with this, mannose-binding lectin (MBL) deposition has been detected in the subepithelial space of the glomerular capillaries (88). MBL may bind to specific carbohydrates present in PLA2R or THSD7A, which leads to complement system activation $(89,90)$. Patients with $\mathrm{C} 4$ deficiency also develop IMN, while the classic and lectin pathways cannot be activated in patients with $\mathrm{C} 4$ deficiency. In addition, deposition of factor B in IMN has been reported, which appears to be an indirect evidence of the activation of the AP pathway (91).

Thus, the activation pathway of complement is still unclear (Fig. 5). The development of models does not contribute to the activation pathway of complement. Furthermore, the complement pathways of most models are unclear (Table II). An AP is essential to complement activation in the anti- $\alpha 3 \mathrm{NC1}$ mouse model via factor B knockout (58). The human anti-THSD7A-related mouse model provides an opportunity to use genetic intervention in complement activation. In addition, it might be useful to omit complement activation and attack podocytes with MAC (C5b-9).

The next focus is antigen exposure in human MN. Several reported cases of $\mathrm{MN}$ might aid our understanding of the research question. One example is the case of a 40 -year-old female patient with THSD7A-associated MN concomitant with mixed adenoneuroendocrine carcinoma of the gallbladder. THSD7A was detected in her gallbladder tumor, which corresponded to the immunohistochemical test result. No anti-THSD7A 


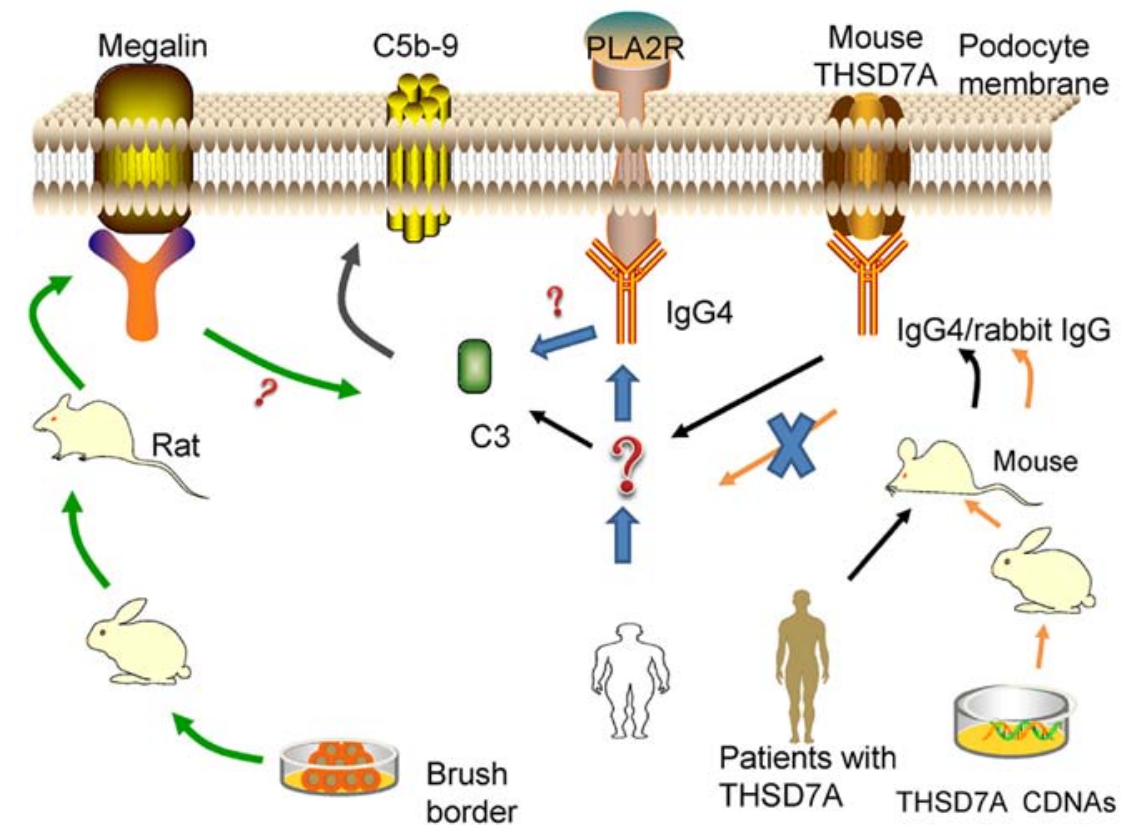

Figure 5. Pathogenesis of the human IMN, passive Heymann nephritis and THSD7A-associated models. The common pathogenic mechanism is the combination of autoantibodies and autoantigens activating the complement system and then inducing the production of a complement membrane complex (C5b-9) to damage podocytes. However, the activation pathway of complement is unclear and no complement was involved in the heterologous model (rabbit) of THSD7A-associated MN. IMN, Idiopathic membranous nephropathy; THSD7A, thrombospondin type-1 domain-containing 7A; MN, membranous nephropathy; PLA2R, phospholipase A2 receptor; IgG, immunoglobulin G.

antibodies were detected in the plasma and her urinary protein level decreased significantly after chemotherapy (92). Another example is that of two patients with THSD7A-associated MN accompanied by angiolymphoid hyperplasia with eosinophilia. THSD7A expression outside the kidney may be vital to the pathogenesis of IMN (93). These cases seem to indicate that antibodies produced outside the kidney help with the initial recognition of antigens. However, the aforementioned cases have limitations. Electron microscopy observation results were not reported in the articles, so whether the diagnosis of $\mathrm{SMN}$ is consistent is uncertain. In addition, a cross-sectional study (94) found a significant correlation between the incidence of IMN and exposure of particulate matter of $<2.5\left(\mathrm{PM}_{2.5}\right)$. In areas with severe air pollution, the incidence of IMN increased significantly. PLA2R can be found in neutrophils and the lung $(95,96)$. In addition, PLA2R and THSD7A are disparate paths to the same disease (97). Thus, the authors of the present review may hypothesize that an unidentified extrarenal cause exists in IMN or SMN.

The authors of the present review hypothesized that tumor tissues overexpress THSD7A, or PLA2R is expressed in neutrophils and lung cells, which leads to complement system activation and MAC formation $(92,93,98)$. However, the current models do not help us answer the question of antigen production. Most current models were established by injecting antibodies produced heterogeneously. This approach is not helpful for examining the original antigens in human IMN. To clarify whether an undiscovered mechanism exists, a more appropriate model with PLA2R-expressing podocytes should be established.

Finally, the reason that IgG4 is the most common antibody deposited in the subepithelial immune complex in most human IMN types remains unclear. IgG4 is related to inflammation and autoimmune disorders (99), but it is widely found in IMN. A previous study suggested that IgG4 could have a partially protective effect by acting on IgG1 or IgG3 (100). Another study suggested that IgG autoantibodies transform from IgG1 to IgG4 during disease progression (101). Probably owing to the different antigens or ways antibodies are induced, only few known models detect IgG4 (Table II). IgG4 is the main antibody of the THSD7A-associated MN model. Whether purified anti-THSD7A IgG4 can form immune deposits in this model will likely advance IgG4 research

Evidence of the significant correlation between specific genetic factors and IMN is accumulating $(102,103)$. The human leukocyte antigen (HLA) gene has a strong gene correlation with the $P L A 2 R$ gene and the interaction may be the basis of autoimmune injury (104). Although no relevant study has described the polymorphism of the THSD7A gene, the combined application of THSD7A and PLA2R gene tests is helpful to further examine the correlation between the IMN pathogenesis and genes, providing an important value for the establishment of the genetic model of MN.

\section{Potential future models}

Future rodent model with C5b-9 attacks. In human $\mathrm{MN}$, three complement activation pathways have been reported, but reports about each pathway are conflicting. The common feature is that complement activation induces assembly of the MAC (C5b-9) on podocytes, which is necessary for sublethal damage to the renal intrinsic cells (22). Therefore, establishing a model with MAC (C5b-9) podocytes may avoid the disadvantages of the difference in pathways between the models and human MN (Fig. 6). First, sublytic C5b-9 is assembled in vitro and then incubated with microbubbles that carry cationic 


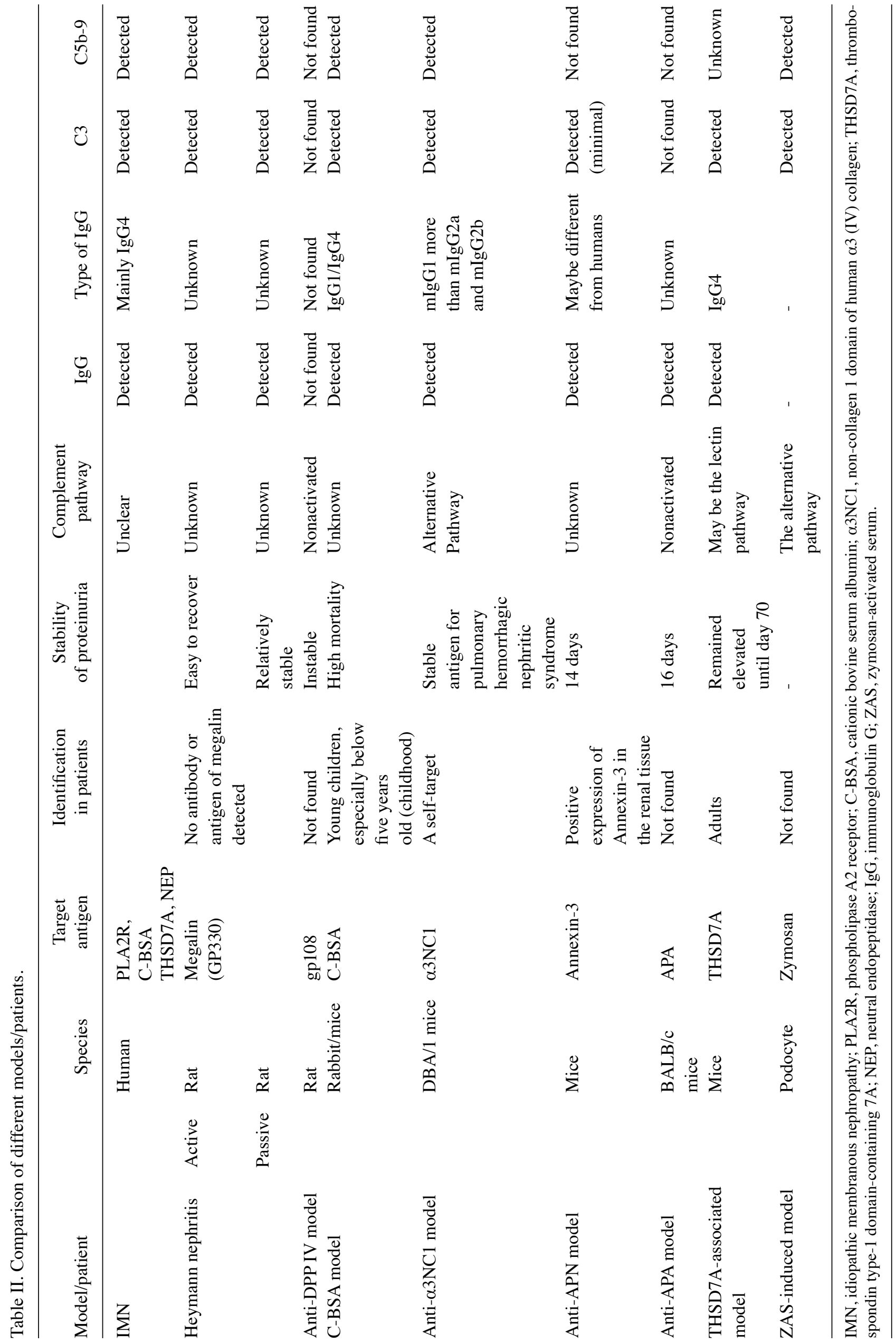




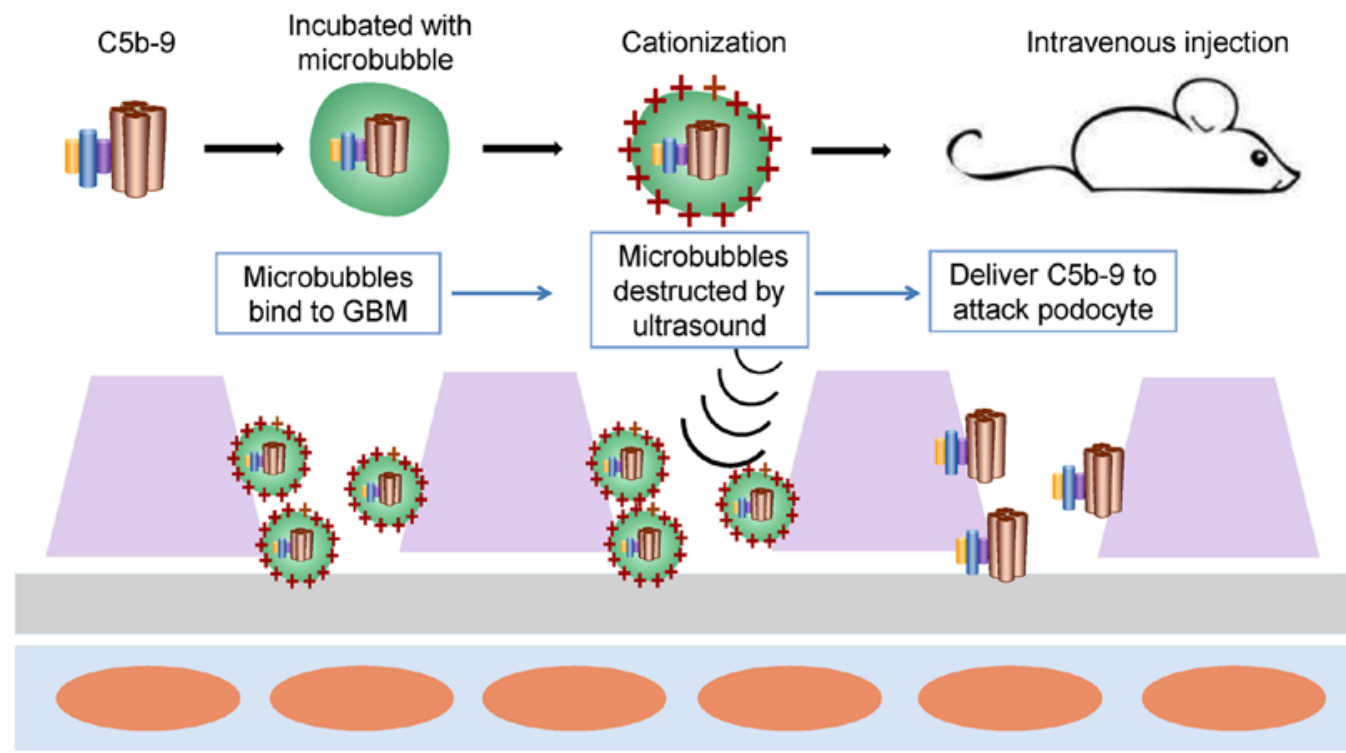

Figure 6. Future rodent model with C5b-9 attacks. First, sublytic C5b-9 is assembled in vitro and then incubated with microbubbles that carry cationic charges by using the ultrasonic targeted microbubble destruction technology $(103,104)$. Then, the suspension of microvesicles is injected immediately in the mice intravenously. Microvesicles are likely to contact with the glomerular basement membrane and podocytes as a result of carrying cationic charges. Ultrasonic sensors are used to scan the kidney repeatedly and when microbubbles are observed traveling into the kidney, the ultrasonic pressure will be increased to destroy the microbubbles, delivering C5b-9 to attack podocytes. GBM, glomerular basement membrane.

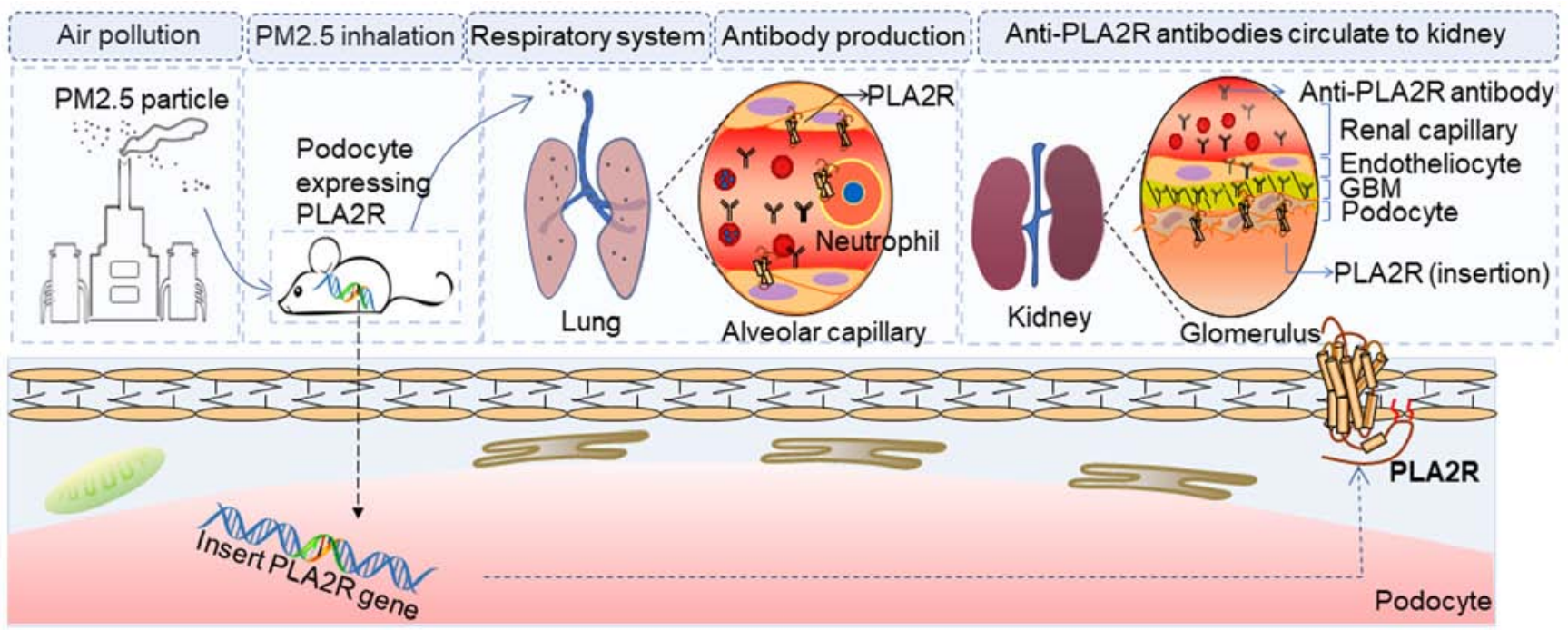

Figure 7. Future rodent model with podocytes expressing PLA2R. A rodent model with podocytes expressing PLA2R was established by gene insertion. Using PM 2.5 to stimulate mice with podocytes expressing PLA2R may induce a lung or systemic inflammatory response and then expose the PLA2R in the lung or neutrophils. Furthermore, antibodies circulate in the blood and finally bind to the podocytes, eventually causing podocyte injury due to the immunoreaction. PLA2R, phospholipase A2 receptor; PM, particulate matter.

charges. The specific steps follow the protocol provided by ultrasonic-targeted microbubble destruction $(105,106)$. Then, the suspension of microvesicles is injected immediately in mice through the tail vein. Microvesicles are likely to contact the GBM and podocytes because they carry cationic charges. Ultrasonic sensors are used to scan the kidney repeatedly and when microbubbles are observed traveling into the kidney, the ultrasonic pressure will be increased to destroy the microbubbles, delivering C5b-9 to attack podocytes.

Future rodent model with PLA2R-expressing podocytes. PLA2R is a glycoprotein constituent located on the podocytes of healthy humans $(107,108)$. It is a type I transmembrane receptor and a member of the mannose-receptor family (109). It was identified in immune deposits in $70-80 \%$ of patients with IMN, but PLA2R was not detected in the glomeruli of healthy rodents or rabbits (63). According to the PubMed genetic database (Gene ID: 18779, https://www.ncbi.nlm.nih. gov/gene/?term=18779), mice express PLA2R in the kidneys. Thus, establishing a rodent model with podocytes expressing PLA2R may contribute to the advancement of PLA2R-related human MN (Fig. 7).

Subsequently, the anti-PLA2R antibody can be injected to induce IMN. In addition, as mentioned previously, several 
extrarenal factors may activate the autoimmune system to produce anti-PLA2R antibody. Previous findings have shown that PLA2R-deficient mice had significantly expressed inflammatory cells around the airways as compared with wild-type mice (110). Thus, using $\mathrm{PM}_{2.5}$ to stimulate mice with podocytes expressing PLA2R, may expose PLA2R in the lung or neutrophils and then generating antibodies to bind to podocytes.

An ideal model is the one that will contribute to understand the pathogenesis of IMN, so as to improve the diagnosis and therapy. It is worth noting that increasing evidence has shown the traditional Chinese medicine (TCM) is beneficial for both antifibrosis therapy in CKD (111-113) and treating primary disease such as IMN (114-116). However, their mechanisms have not been elucidated. TCM could bring a new understanding of the pathogenesis of IMN.

\section{Acknowledgements}

Not applicable.

\section{Funding}

The present study was supported by National Major Scientific and Technological Special Project for 'Significant New Drugs Development' (grant no. 2017ZX09304019).

\section{Availability of data and materials}

All data generated or analyzed during this study are included in this published article.

\section{Authors' contributions}

HXJ and ZF wrote the main parts of this manuscript; ZBZ, $\mathrm{CHX}, \mathrm{WZ}$ and JG wrote other parts and designed the figures; BLL and YW improved the language of the manuscript; YNL and WJL conceived the structure and revised the manuscript. All authors read and approved the final manuscript.

\section{Ethics approval and consent to participate}

Not applicable.

\section{Patient consent for publication}

Not applicable.

\section{Competing interests}

The authors declare that they have no competing interests.

\section{References}

1. Cernaro V, Coppolino G, Visconti L, Rivoli L, Lacquaniti A, Santoro D, Buemi A, Loddo S and Buemi M: Erythropoiesis and chronic kidney disease-related anemia: From physiology to new therapeutic advancements. Med Res Rev 39: 427-460, 2019.

2. Chen DQ, Cao G, Chen H, Argyopoulos CP, Yu H, Su W, Chen L, Samuels DC, Zhuang S, Bayliss GP, et al: Identification of serum metabolites associating with chronic kidney disease progression and anti-fibrotic effect of 5-methoxytryptophan. Nat Commun 10: 1476, 2019.
3. Chen DQ, Cao G, Zhao H, Chen L, Yang T, Wang M, Vaziri ND, Guo Y and Zhao YY: Combined melatonin and poricoic acid A inhibits renal fibrosis through modulating the interaction of Smad 3 and $\beta$-catenin pathway in AKI-to-CKD continuum. Ther Adv Chronic Dis 10: 2040622319869116, 2019.

4. MacKinnon HJ, Wilkinson TJ, Clarke AL, Gould DW, O'Sullivan TF, Xenophontos S, Watson EL, Singh SJ and Smith AC: The association of physical function and physical activity with all-cause mortality and adverse clinical outcomes in nondialysis chronic kidney disease: A systematic review. Ther Adv Chronic Dis 9: 209-226, 2018.

5. Xiaofan H, Jing X, Chenni G, Yifan W, Xialian Y, Li L, Hong R, Wen Z, Weiming W, Xiaoxia P, et al: New risk score for predicting progression of membranous nephropathy. J Transl Med 17: 41, 2019.

6. Petrosyan A, Cravedi P, Villani V, Angeletti A, Manrique J, Renieri A, De Filippo RE, Perin L and Da Sacco S: A glomerulus-on-a-chip to recapitulate the human glomerular filtration barrier. Nat Commun 10: 3656, 2019.

7. Glassock RJ: The pathogenesis of idiopathic membranous nephropathy: A 50-year odyssey. Am J Kidney Dis 56: 157-167, 2010.

8. Xu X, Wang G, Chen N, Lu T, Nie S, Xu G, Zhang P, Luo Y, Wang Y, Wang X, et al: Long-term exposure to air pollution and increased risk of membranous nephropathy in China. J Am Soc Nephrol 27: 3739-3746, 2016.

9. Zhu P, Zhou FD, Wang SX, Zhao MH and Wang HY: Increasing frequency of idiopathic membranous nephropathy in primary glomerular disease: A 10-year renal biopsy study from a single Chinese nephrology centre. Nephrology (Carlton) 20: 560-566, 2015.

10. Pan X, Xu J, Ren H, Zhang W, Xu Y, Shen P, Li X, Wang W, Chen $\mathrm{X}, \mathrm{Wu} \mathrm{P}$, et al: Changing spectrum of biopsy-proven primary glomerular diseases over the past 15 years: A single-center study in China. Contrib Nephrol 181: 22-30, 2013.

11. Chen X, Chen Y, Shi K, Lv Y, Tong H, Zhao G, Chen C, Chen B, $\mathrm{Li}$ D and Lu Z: Comparison of prognostic, clinical, and renal histopathological characteristics of overlapping idiopathic membranous nephropathy and IgA nephropathy versus idiopathic membranous nephropathy. Sci Rep 7: 11468, 2017.

12. Maisonneuve P, Agodoa L, Gellert R, Stewart JH, Buccianti G, Lowenfels AB, Wolfe RA, Jones E, Disney AP, Briggs D, et al: Distribution of primary renal diseases leading to end-stage renal failure in the United States, Europe, and Australia/New Zealand: Results from an international comparative study. Am J Kidney Dis 35: 157-165, 2000.

13. Latt KZ, Honda K, Thiri M, Hitomi Y, Omae Y, Sawai H, Kawai Y, Teraguchi S, Ueno K, Nagasaki M, et al: Identification of a two-SNP PLA2R1 Haplotype and HLA-DRB1 Alleles as primary risk associations in idiopathic membranous nephropathy. Sci Rep 8: 15576, 2018.

14. Couser WG: Primary Membranous Nephropathy. Clin J Am Soc Nephrol 12: 983-997, 2017.

15. Troyanov S, Wall CA, Scholey JW, Miller JA and Cattran DC: Idiopathic membranous nephropathy: Definition and relevance of a partial remission. Kidney International 66: 1199-1205, 2004.

16. Cattran D and Brenchley P: Membranous nephropathy: Thinking through the therapeutic options. Nephrol Dial Transplant 32: i22-i29, 2017.

17. Fontecha-Barriuso M, Martin-Sanchez D, Ruiz-Andres O, Poveda J, Sanchez-Niño MD, Valiño-Rivas L, Ruiz-Ortega M, Ortiz A and Sanz AB: Targeting epigenetic DNA and histone modifications to treat kidney disease. Nephrol Dial Transplant 33: 1875-1886, 2018.

18. Jefferson JA, Pippin JW and Shankland SJ: Experimental models of membranous nephropathy. Drug Discov Today Dis Models 7: 27-33, 2010.

19. Borza DB, Zhang JJ, Beck LH Jr, Meyer-Schwesinger C and Luo W: Mouse models of membranous nephropathy: The road less travelled by. Am J Clin Exp Immunol 2: 135-145, 2013.

20. Tomas NM, Hoxha E, Reinicke AT, Fester L, Helmchen U, Gerth J, Bachmann F, Budde K, Koch-Nolte F, Zahner G, et al: Autoantibodies against thrombospondin type 1 domain-containing 7A induce membranous nephropathy. J Clin Invest 126: 2519-2532, 2016.

21. Lim WH, Wong G, McDonald SP, Chakera A, Luxton G, Isbel NM, Pilmore HL, Barbour T, Hughes P and Chadban SJ: Long-term outcomes of kidney transplant recipients with end-stage kidney disease attributed to presumed/advanced glomerulonephritis or unknown cause. Sci Rep 8: 9021, 2018. 
22. Cybulsky AV, Quigg RJ and Salant DJ: Experimental membranous nephropathy redux. Am J Physiol Renal Physiol 289: F660-F671, 2005.

23. Ma H, Sandor DG and Beck LH Jr: The role of complement in membranous nephropathy. Semin Nephrol 33: 531-542, 2013.

24. Heymann W, Hackel DB, Harwood S, Wilson SG and Hunter JL: Production of nephrotic syndrome in rats by Freund's adjuvants and rat kidney suspensions. Proc Soc Exp Biol Med 100: 660-664, 1959

25. Salant DJ, Quigg RJ and Cybulsky AV: Heymann nephritis: Mechanisms of renal injury. Kidney Int 35: 976-984, 1989.

26. Christiansen RE, Kolmannskog O, Leh S, Iversen BM and Tenstad O: Glomerular charge barrier and development of proteinuria in passive Heymann nephritis. Kidney Blood Press Res 31: 203-209, 2008.

27. Salant DJ and Cybulsky AV: Experimental glomerulonephritis. Methods Enzymol 162: 421-461, 1988.

28. Kerjaschki D and Farquhar MG: The pathogenic antigen of Heymann nephritis is a membrane glycoprotein of the renal proximal tubule brush border. Proc Natl Acad Sci USA 79: 5557-5561, 1982.

29. Kerjaschki D and Farquhar MG: Immunocytochemical localization of the Heymann nephritis antigen (GP330) in glomerular epithelial cells of normal Lewis rats. J Exp Med 157: 667-686, 1983.

30. Kerjaschki D, Ullrich R, Diem K, Pietromonaco S, Orlando RA and Farquhar MG: Identification of a pathogenic epitope involved in initiation of Heymann nephritis. Proc Natl Acad Sci USA 89: 11179-11183, 1992

31. Raychowdhury R, Zheng G, Brown D and McCluskey RT: Induction of Heymann nephritis with a gp330/megalin fusion protein. Am J Pathol 148: 1613-1623, 1996.

32. Couser WG: Mediation of immune glomerular injury. J Am Soc Nephrol 1: 13-29, 1990.

33. Baker PJ, Ochi RF, Schulze M, Johnson RJ, Campbell $\mathrm{C}$ and Couser WG: Depletion of C6 prevents development of proteinuria in experimental membranous nephropathy in rats. Am J Pathol 135: 185-194, 1989.

34. Prabakaran T, Nielsen R, Larsen JV, Sørensen SS Feldt-Rasmussen U, Saleem MA, Petersen CM, Verroust PJ and Christensen EI: Receptor-mediated endocytosis of $\alpha$-galactosidase A in human podocytes in Fabry disease. PLoS One 6: e25065, 2011.

35. Larsen C, Etzerodt A, Madsen M, Skjodt K, Moestrup SK and Andersen CBF: Structural assembly of the megadalton-sized receptor for intestinal vitamin $B_{12}$ uptake and kidney protein reabsorption. Nat Commun 9: 5204, 2018.

36. Ronco P and Debiec H: Pathophysiological advances in membranous nephropathy: Time for a shift in patient's care. Lancet 385 : 1983-1992, 2015

37. Vinaiphat $A$ and Thongboonkerd V: Characterizations of PMCA2-interacting complex and its role as a calcium oxalate crystal-binding protein. Cell Mol Life Sci 75: 1461-1482, 2018.

38. Beausang JF, Fan HC, Sit R, Hutchins MU, Jirage K, Curtis R, Hutchins E, Quake SR and Yabu JM: B cell repertoires in HLA-sensitized kidney transplant candidates undergoing desensitization therapy. J Transl Med 15: 9, 2017.

39. Rudkin FM, Raziunaite I, Workman H, Essono S, Belmonte R, MacCallum DM, Johnson EM, Silva LM, Palma AS, Feizi T, et al: Single human B cell-derived monoclonal anti-Candida antibodies enhance phagocytosis and protect against disseminated candidiasis. Nat Commun 9: 5288, 2018.

40. Natori Y, Shindo N and Natori Y: Proteinuria induced by anti-dipeptidyl peptidase IV (gp108); role of circulating and glomerular antigen. Clin Exp Immunol 95: 327-332, 1994.

41. Hunter JL, Hackel DB and Heymann W: Nephrotic syndrome in rats produced by sensitization to rat kidney proteins: Immunologic studies. J Immunol 85: 319-327, 1960

42. Tomas NM, Beck LH Jr, Meyer-Schwesinger C, Seitz-Polski B, Ma H, Zahner G, Dolla G, Hoxha E, Helmchen U, Dabert-Gay AS, et al: Thrombospondin type-1 domain-containing 7A in idiopathic membranous nephropathy. N Engl J Med 371: 2277-2287, 2014

43. Glassock RJ: Pathogenesis of membranous nephropathy: A new paradigm in evolution. Contrib Nephrol 181: 131-142, 2013.

44. Tan K, Duquette M, Liu JH, Dong Y, Zhang R, Joachimiak A, Lawler J and Wang JH: Crystal structure of the TSP-1 type 1 repeats: A novel layered fold and its biological implication. J Cell Biol 159: 373-382, 2002 .
45. Allison SJ: Glomerular disease: Thrombospondin type-1 domain-containing 7A-a new player in membranous nephropathy. Nat Rev Nephrol 11: 63, 2015.

46. De Vriese AS, Glassock RJ, Nath KA, Sethi S and Fervenza FC: A Proposal for a serology-based approach to membranous nephropathy. J Am Soc Nephrol 28: 421-430, 2017.

47. Godel M, Grahammer F and Huber TB: Thrombospondin type-1 domain-containing 7A in idiopathic membranous nephropathy. N Engl J Med 372: 1073, 2015.

48. Tomas NM, Meyer-Schwesinger C, von Spiegel H, Kotb AM, Zahner G, Hoxha E, Helmchen U, Endlich N, Koch-Nolte F and Stahl RAK: A Heterologous model of thrombospondin type 1 domain-containing 7A-associated membranous nephropathy. J Am Soc Nephrol 28: 3262-3277, 2017

49. Assmann KJ, van Son JP, Dijkman HB and Koene RA: A nephritogenic rat monoclonal antibody to mouse aminopeptidase A. Induction of massive albuminuria after a single intravenous injection. J Exp Med 175: 623-635, 1992.

50. Dijkman HB, Gerlofs-Nijland ME, van der Laak JA, Wetzels JF, Groenen PJ and Assmann KJ: Podocyte changes after induction of acute albuminuria in mice by anti-aminopeptidase $\mathrm{A} \mathrm{mAb}$ Nephron Exp Nephrol 94: e85-e93, 2003.

51. Border WA, Ward HJ, Kamil ES and Cohen AH: Induction of membranous nephropathy in rabbits by administration of an exogenous cationic antigen. J Clin Invest 69: 451-461, 1982.

52. Liu B, Lu R, Li H, Zhou Y, Zhang P, Bai L, Chen D, Chen J, Li J, Yu P, et al: Zhen-wu-tang ameliorates membranous nephropathy rats through inhibiting NF- $\mathrm{BB}$ pathway and NLRP3 inflammasome. Phytomedicine 59: 152913, 2019.

53. Adler SG, Wang H, Ward HJ, Cohen AH and Border WA Electrical charge. Its role in the pathogenesis and prevention of experimental membranous nephropathy in the rabbit. J Clin Invest 71: 487-499, 1983.

54. Chen JS, Chen A, Chang LC, Chang WS, Lee HS, Lin SH and Lin YF: Mouse model of membranous nephropathy induced by cationic bovine serum albumin: Antigen dose-response relations and strain differences. Nephrol Dial Transplant 19: 2721-2728, 2004.

55. Debiec H, Lefeu F, Kemper MJ, Niaudet P, Deschênes G, Remuzzi G, Ulinski T and Ronco P: Early-childhood membranous nephropathy due to cationic bovine serum albumin. N Engl J Med 364: 2101-2110, 2011

56. Zhang JJ, Malekpour M, Luo W, Ge L, Olaru F, Wang XP, Bah M, Sado Y, Heidet L, Kleinau S, et al: Murine membranous nephropathy: Immunization with $\alpha 3$ (IV) collagen fragment induces subepithelial immune complexes and $\mathrm{Fc} \gamma \mathrm{R}$-independent nephrotic syndrome. J Immunol 188: 3268-3277, 2012.

57. Hopfer H, Hunemorder S, Treder J, Turner JE, Paust HJ, Meyer-Schwesinger C, Hopfer U, Sachs M, Peters A, Bucher-Kocaoglu B, et al: Glomerulopathy induced by immunization with a peptide derived from the goodpasture antigen a3IV-NC1. J Immunol 194: 3646-3655, 2015.

58. Luo W, Olaru F, Miner JH, Beck LH Jr, van der Vlag J, Thurman JM and Borza DB: Alternative pathway is essential for glomerular complement activation and proteinuria in a mouse model of membranous nephropathy. Front Immunol 9: 1433, 2018.

59. Hopfer H, Maron R, Butzmann U, Helmchen U, Weiner HL and Kalluri R: The importance of cell-mediated immunity in the course and severity of autoimmune anti-glomerular basement membrane disease in mice. FASEB J 17: 860-868, 2003.

60. Meyer TN, Schwesinger C, Wahlefeld J, Dehde S, Kerjaschki D, Becker JU, Stahl RA and Thaiss F: A new mouse model of immune-mediated podocyte injury. Kidney Int 72: 841-852, 2007.

61. Tsai SF, Wu MJ and Chen $\mathrm{CH}$ : Low serum $\mathrm{C} 3$ level, high neutrophil-lymphocyte-ratio, and high platelet-lymphocyte-ratio all predicted poor long-term renal survivals in biopsy-confirmed idiopathic membranous nephropathy. Scie Rep 9: 6209, 2019.

62. Meyer-Schwesinger C, Dehde S, Klug P, Becker JU, Mathey S, Arefi K, Balabanov S, Venz S, Endlich KH, Pekna M, et al: Nephrotic syndrome and subepithelial deposits in a mouse model of immune-mediated anti-podocyte glomerulonephritis. J Immunol 187: 3218-3229, 2011.

63. Beck LH Jr, Bonegio RG, Lambeau G, Beck DM, Powell DW, Cummins TD, Klein JB and Salant DJ: M-type phospholipase A2 receptor as target antigen in idiopathic membranous nephropathy. N Engl J Med 361: 11-21, 2009.

64. Debiec $\mathrm{H}$ and Ronco P: Immune response against autoantigen PLA2R is not gambling: Implications for pathophysiology, prognosis, and therapy. J Am Soc Nephrol 27: 1275-1277, 2016. 
65. Pandey P, Roy KK, Liu H, Ma G, Pettaway S, Alsharif WF Gadepalli RS, Rimoldi JM, McCurdy CR, Cutler SJ and Doerksen RJ: Structure-based identification of potent natural product chemotypes as cannabinoid receptor 1 inverse agonists. Molecules 23: pii: E2630, 2018.

66. Wang J, Cui Z, Lu J, Probst C, Zhang YM, Wang X, Qu Z, Wang F, Meng LQ, Cheng XY, et al: Circulating antibodies against thrombospondin type-I domain-containing 7A in Chinese patients with idiopathic membranous nephropathy. Clin J Am Soc Nephrol 12: 1642-1651, 2017.

67. Liu W, Gao C, Dai H, Zheng Y, Dong Z, Gao Y, Liu F, Zhang Z, Liu Z, Liu W, et al: Immunological pathogenesis of membranous nephropathy: Focus on PLA2R1 and Its role. Front Immunol 10 1809,2019

68. Song JS, Kim YJ, Han KU, Yoon BD and Kim JW: Zymosan and PMA activate the immune responses of Mutz3-derived dendritic cells synergistically. Immunol Lett 167: 41-46, 2015.

69. Gawryl MS, Simon MT, Eatman JL and Lint TF: An enzyme-linked immunoabsorbent assay for the quantitation of the terminal complement complex from cell membranes or in activated human sera. J Immunol Methods 95: 217-225, 1986.

70. Ishikawa S, Tsukada $\mathrm{H}$ and Bhattacharya J: Soluble complex of complement increases hydraulic conductivity in single microvessels of rat lung. J Clin Invest 91: 103-109, 1993.

71. Liu WJ, Li ZH, Chen XC, Zhao XL, Zhong Z, Yang C, Wu HL, An N, Li WY and Liu HF: Blockage of the lysosome-dependent autophagic pathway contributes to complement membrane attack complex-induced podocyte injury in idiopathic membranous nephropathy. Sci Rep 7: 8643, 2017.

72. Fearon DT and Austen KF: Activation of the alternative complement pathway due to resistance of zymosan-bound amplification convertase to endogenous regulatory mechanisms. Proc Natl Acad Sci USA 74: 1683-1687, 1977.

73. Tegla CA, Cudrici C, Patel S, Trippe R III, Rus V, Niculescu F and Rus H: Membrane attack by complement: The assembly and biology of terminal complement complexes. Immunol Res 51: 45-60, 2011.

74. Harboe M, Garred P, Lindstad JK, Pharo A, Müller F, Stahl GL, Lambris JD and Mollnes TE: The role of properdin in zymosan- and Escherichia coli-induced complement activation. J Immunol 189: 2606-2613, 2012.

75. Rawal N and Pangburn MK: C5 convertase of the alternative pathway of complement. Kinetic analysis of the free and surface-bound forms of the enzyme. J Biol Chem 273: 16828-16835, 1998.

76. Rawal N and Pangburn M: Formation of high-affinity C5 convertases of the alternative pathway of complement. J Immunol 166 : 2635-2642, 2001.

77. Zhang MH, Fan JM, Xie XS, Deng YY, Chen YP, Zhen R, Li J, Cheng Y and Wen J: Ginsenoside-Rg1 protects podocytes from complement mediated injury. J Ethnopharmacol 137: 99-107, 2011

78. Zhang C, Leng L, Zhang X, Zhao Y and Li Z: Comprehensive identification of immune-associated biomarkers based on network and mRNA expression patterns in membranous glomerulonephritis. J Transl Med 16: 210, 2018.

79. Bruschi M,Petretto A, SantucciL, Vaglio A,PratesiF, MiglioriniP, Bertelli R, Lavarello C, Bartolucci M, Candiano G, et al: Neutrophil Extracellular Traps protein composition is specific for patients with Lupus nephritis and includes methyl-oxidized alphaenolase (methionine sulfoxide 93). Scie Rep 9: 7934, 2019.

80. Li LZ, Hu Y, Ai SL, Cheng L, Liu J, Morris E, Li Y, Gou SJ and Fu P: The relationship between thyroid dysfunction and nephrotic syndrome: A clinicopathological study. Sci Rep 9: 6421, 2019.

81. Pozdzik A, Brocheriou I, David C, Touzani F, Goujon JM and Wissing KM: Membranous nephropathy and anti-podocytes antibodies: Implications for the diagnostic workup and disease management. Biomed Res Int 2018: 6281054, 2018.

82. Borsos T: Immune complex mediated activation of the classic complement pathway. Behring Inst Mitt 93-101, 1989.

83. Cattran DC and Brenchley PE: Membranous nephropathy: Integrating basic science into improved clinical management. Kidney Int 91: 566-574, 2017.

84. Zhang Q, Huang B, Liu X, Liu B, Zhang Y, Zhang Z, Hua J, Fan Y, Hu L, Meng M, et al: Ultrasensitive quantitation of anti-phospholipase A2 receptor antibody as a diagnostic and prognostic indicator of idiopathic membranous nephropathy. Sci Rep 7: 12049, 2017.

85. Fresquet M, Jowitt TA, McKenzie EA, Ball MD, Randles MJ, Lennon R and Brenchley PE: PLA $R$ binds to the annexin A2-S100A10 complex in human podocytes. Sci Rep 7: 6876, 2017
86. Vidarsson G, Dekkers G and Rispens T: IgG subclasses and allotypes: From structure to effector functions. Front Immunol 5: 520, 2014.

87. Borza DB: Alternative pathway dysregulation and the conundrum of complement activation by IgG4 immune complexes in membranous nephropathy. Front Immunol 7: 157, 2016.

88. Wang Z, Wen L, Dou Y and Zhao Z: Human anti-thrombospondin type 1 domain-containing 7A antibodies induce membranous nephropathy through activation of lectin complement pathway. Biosci Rep 38: pii: BSR20180131, 2018

89. Hayashi N, Okada K, Matsui Y,Fujimoto K, Adachi H, Yamaya H, Matsushita $\mathrm{M}$ and Yokoyama H: Glomerular mannose-binding lectin deposition in intrinsic antigen-related membranous nephropathy. Nephrol Dial Transplant 33: 832-840, 2018.

90. Garred P, Genster N, Pilely K, Bayarri-Olmos R, Rosbjerg A, Ma YJ and Skjoedt MO: A journey through the lectin pathway of complement-MBL and beyond. Immunol Rev 274: 74-97, 2016.

91. Bally S, Debiec H, Ponard D, Dijoud F, Rendu J, Fauré J, Ronco P and Dumestre-Perard C: Phospholipase A2 Receptor-related membranous nephropathy and mannan-binding lectin deficiency. J Am Soc Nephrol 27: 3539-3544, 2016.

92. Hoxha E, Wiech T, Stahl PR, Zahner G, Tomas NM, Meyer-Schwesinger C, Wenzel U, Janneck M, Steinmetz OM, Panzer U, et al: A mechanism for Cancer-associated membranous nephropathy. N Engl J Med 374: 1995-1996, 2016.

93. Matsumoto A, Matsui I, Namba T, Sakaguchi Y, Mizuno H, Shirayama Y, Shimada K, Hashimoto N, Doi Y, Yamaguchi S, et al: VEGF-A links angiolymphoid hyperplasia with eosinophilia (ALHE) to THSD7A membranous nephropathy: A report of 2 cases. Am J Kidney Dis 73: 880-885, 2019.

94. Xu X, Wang G, Chen N, Lu T, Nie S, Xu G, Zhang P, Luo Y, Wang Y, Wang X, et al: Long-term exposure to air pollution and increased risk of membranous nephropathy in China. J Am Soc Nephrol 27: 3739-3746, 2016.

95. Silliman CC, Moore EE, Zallen G, Gonzalez R, Johnson JL, Elzi DJ, Meng X, Hanasaki K, Ishizaki J, Arita H, et al: Presence of the M-type SPLA(2) receptor on neutrophils and its role in elastase release and adhesion. Am J Physiol Cell Physiol 283: C1102-C1113, 2002

96. Granata F, Petraroli A, Boilard E, Bezzine S, Bollinger J, Del Vecchio L, Gelb MH, Lambeau G, Marone G and Triggiani M: Activation of cytokine production by secreted phospholipase A2 in human lung macrophages expressing the M-type receptor. J Immunol 174: 464-474, 2005

97. Beck LH Jr: PLA2R and THSD7A: Disparate paths to the same disease? J Am Soc Nephrol 28: 2579-2589, 2017.

98. Chiorazzo MG, Tunset HM, Popov AV, Johansen B, Moestue S and Delikatny EJ: Detection and differentiation of breast cancer Sub-types using a cPLA2 $\alpha$ activatable fluorophore. Sci Rep 9: $6122,2019$.

99. Pan Q, Lan Q, Peng Y, Cai J, Zheng J, Dickerson C, Xiao H and Liu HF: Nature, functions, and clinical implications of IgG4 autoantibodies in systemic lupus erythematosus and rheumatoid arthritis. Discov Med 23: 169-174, 2017.

100. Salant DJ: Unmet challenges in membranous nephropathy. Curr Opin Nephrol Hypertens 28: 70-76, 2019.

101. Borza DB: Alternative pathway dysregulation and the conundrum of complement activation by IgG4 immune complexes in membranous nephropathy. Front Immunol 7: 157, 2016.

102. Liu D, Zhang J, Shi Y and Liu Z: Gene polymorphism and risk of idiopathic membranous nephropathy. Life Sci 229: 124-131, 2019.

103. Canadas-Garre M, Anderson K, McGoldrick J, Maxwell AP and McKnight AJ: Genomic approaches in the search for molecular biomarkers in chronic kidney disease. J Transl Med 16: 292, 2018.

104. Kamyshova ES, Bobkova IN, Gorelova IA, Kakhsurueva PA and Filatova EE: Genetic determinants of the development and course of membranous nephropathy. Ter Arkh 90: 105-111, 2018.

105. Lan HY, Mu W, Tomita N, Huang XR, Li JH,Zhu HJ, Morishita R and Johnson RJ: Inhibition of renal fibrosis by gene transfer of inducible Smad7 using ultrasound-microbubble system in rat UUO model. J Am Soc Nephrol 14: 1535-1548, 2003.

106. Fujii H, Li SH, Wu J, Miyagi Y, Yau TM, Rakowski H, Egashira K, Guo J, Weisel RD and Li RK: Repeated and targeted transfer of angiogenic plasmids into the infarcted rat heart via ultrasound targeted microbubble destruction enhances cardiac repair. Eur Heart J 32: 2075-2084, 2011.

107. Huang B, Wang L, Zhang Y, Zhang J, Zhang Q, Xiao H, Zhou B, Sun Z, Cao YN, Chen Y, et al: A novel Time-resolved Fluoroimmunoassay for the quantitative detection of Antibodies against the phospholipase A2 receptor. Sci Rep 7: 46096, 2017. 
108. Pan Y, Wan J, Liu Y, Yang Q, Liang W, Singhal PC, Saleem MA and Ding G: sPLA2 IB induces human podocyte apoptosis via the M-type phospholipase A2 receptor. Sci Re 4: 6660, 2014.

109. Lambeau $\mathrm{G}$ and Lazdunski M: Receptors for a growing family of secreted phospholipases A2. Trends Pharmacol Sci 20: $162-170,1999$.

110. Tamaru S, Mishina H, Watanabe Y, Watanabe K, Fujioka D, Takahashi S, Suzuki K, Nakamura T, Obata JE, Kawabata K, et al: Deficiency of phospholipase A2 receptor exacerbates ovalbumin-induced lung inflammation. J Immunol 191: 1021-1028, 2013

111. Chen DQ, Feng YL, Cao G and Zhao YY: Natural products as a source for antifibrosis therapy. Trends Pharmacol Sci 39: 937-952, 2018.

112. Chen DQ, Hu HH, Wang YN, Feng YL, Cao G and Zhao YY: Natural products for the prevention and treatment of kidney disease. Phytomedicine 50: 50-60, 2018.

113. Wang M, Chen DQ, Chen L, Cao G, Zhao H, Liu D, Vaziri ND, Guo Y and Zhao YY: Novel inhibitors of the cellular renin-angiotensin system components, poricoic acids, target Smad3 phosphorylation and Wnt/beta-catenin pathway against renal fibrosis. Br J Pharmacol 175: 2689-2708, 2018.
114. Chen Y, Deng Y, Ni Z, Chen N, Chen X, Shi W, Zhan Y, Yuan F, Deng $W$ and Zhong Y: Efficacy and safety of traditional Chinese medicine (Shenqi Particle) for patients with idiopathic membranous nephropathy: A multicenter randomized controlled clinical trial. Am J Kidney Dis 62: 1068-1076, 2013.

115. Zhang L, Li P, Xing CY, Zhao JY, He YN, Wang JQ, Wu XF, Liu ZS, Zhang AP, Lin HL, et al: Efficacy and safety of Abelmoschus manihot for primary glomerular disease: A prospective, multicenter randomized controlled clinical trial. Am J Kidney Dis 64: 57-65, 2014.

116. Liu S, Li X, Li H, Liang Q, Chen J and Chen J: Comparison of tripterygium wilfordii multiglycosides and tacrolimus in the treatment of idiopathic membranous nephropathy: A prospective cohort study. BMC Nephrol 16: 200, 2015.

(i) $\Theta$ This work is licensed under a Creative Commons Attribution-NonCommercial-NoDerivatives 4.0 International (CC BY-NC-ND 4.0) License. 